University of Nebraska - Lincoln

DigitalCommons@University of Nebraska - Lincoln

Life History and Ecology of Coyotes in the Mid-Atlantic States: A Summary of the Scientifi c Literature

\author{
Lauren L. Mastro \\ United States Department of Agriculture, lauren.I.mastro@usda.gov
}

Follow this and additional works at: https://digitalcommons.unl.edu/icwdm_usdanwrc

Mastro, Lauren L., "Life History and Ecology of Coyotes in the Mid-Atlantic States: A Summary of the Scientifi c Literature" (2011). USDA National Wildlife Research Center - Staff Publications. 1336.

https://digitalcommons.unl.edu/icwdm_usdanwrc/1336

This Article is brought to you for free and open access by the U.S. Department of Agriculture: Animal and Plant Health Inspection Service at DigitalCommons@University of Nebraska - Lincoln. It has been accepted for inclusion in USDA National Wildlife Research Center - Staff Publications by an authorized administrator of DigitalCommons@University of Nebraska - Lincoln. 


\title{
Life History and Ecology of Coyotes in the Mid-Atlantic States: A Summary of the Scientific Literature
}

\author{
Lauren L. Mastro*
}

\begin{abstract}
Relatively little information has been published on Coyotes in the eastern United States, particularly in the mid-Atlantic region, the last area of the contiguous US to be colonized by Coyotes. Increases in eastern Coyote distribution and abundance have been documented, and concerns about their impact on wildlife and livestock are growing. Information from published and unpublished manuscripts, theses, dissertations, and state wildlife agency records in the mid-Atlantic region were examined and synthesized. This review provides a comprehensive summary of Coyote ecology in the mid-Atlantic for natural resource managers and researchers.
\end{abstract}

\section{Introduction}

Canis latrans Say (Coyote) have expanded their range into the eastern United States over the last 100 years. Increases in distribution and abundance have been recorded and concerns regarding their impact on native wildlife and domestic livestock are growing. In 2005, 35,000 cattle and calves worth $>\$ 20$ million dollars were lost to Coyotes in the eastern US, 3 times the number of animals lost to Coyotes 14 years earlier in 1991 (NASS 1992, 2006). Coyotes are also impacting native wildlife by hybridizing with Canis lupus rufus Audibon and Bachman (Red Wolves), and by preying on Odocoileus virginianus (White-tailed Deer) fawns and endangered shorebird nests. Despite increased interest, few published studies have investigated these impacts, particularly in the mid-Atlantic region. I summarized the existing data on Coyotes in the mid-Atlantic region in an effort to disseminate information, identify gaps in our knowledge, and direct future management and research.

\section{Methods}

I defined the mid-Atlantic area as the states of Delaware, Maryland, North Carolina, Pennsylvania, Virginia, and West Virginia. I used several search engines to ensure a comprehensive review of the literature including AGRICOLA, BIOSIS, Wildlife and Ecological Studies Worldwide, and WorldCat. Additional references were gained by inspecting the literature cited section of each reference. Due to the limited information available on the eastern Coyote, I included theses and dissertations, unpublished manuscripts, and grey literature in the form of reports.

*US Department of Agriculture, Animal and Plant Health Inspection Service, Wildlife Services, National Wildlife Research Center, Logan Field Station, 730 Yokum Street, Elkins, WV 26241; Lauren.L.Mastro@aphis.usda.gov. 


\section{Summary and Discussion}

\section{Spatial and temporal distribution}

Coyotes began moving eastward from their historic range around 1900 (Moore and Parker 1992, Parker 1995). Coyotes colonized the east by moving across Canada north of the Great Lakes and into the northeast, south of the Great Lakes and northeast along the Ohio river, and from Mississippi into the southeastern states (Moore and Parker 1992, Parker 1995). Colonization of the mid-Atlantic occurred primarily from two directions, south from New York (Fener et al. 2005) and northeast from Georgia and Tennessee and, to a lesser extent, east across the Ohio River and along Lake Erie (Parker 1995, Williams et al. 1985). Reports of Coyotes in the mid-Atlantic states were first made in northern Pennsylvania in the late 1930s and early 1940s (Hayden 2003, McGinnis 1979, Williams et al. 1985). Coyotes were first reported in West Virginia's Tucker County in 1950 (Wykle 1999), New Jersey's Passaic County in 1958 (Lund 1975, Moore and Parker 1992), and Virginia's Rockingham County in 1965 (Linzey 1998). Through the 1960s, 1970s, and early 1980s, Coyotes continued to occur sporadically and in low numbers across these states (Linzey 1998, Lund 1975, Wykle 1999). Prior to 1983, only 8 Coyotes had been positively identified in Virginia, and only 6 were positively documented in West Virginia between 1980 and 1985 (Wykle 1999). Coyotes were first reported in Maryland in 1972 (McGinnis 1979), western North Carolina in the early 1980s (DeBow et al. 1998, Lee et al. 1982), and Delaware in the early 1990s (Parker 1995). During the past 10-20 years, mid-Atlantic state wildlife agencies have reported increases in the number of Coyotes harvested by hunters and trappers, suggesting that populations have also increased, although no additional demographic information is available (Fig. 1).

\section{Genetics}

Many authors have noted that the eastern Coyote is larger than the western Coyote (Parker 1995, Way 2007, Way and Proietto 2005), and sometimes displays a melanistic coat (Adams et al. 2003b, Anderson et al. 2009, Parker 1995). These characteristics have raised questions about the genetic origins of the eastern Coyote. In the mid-Atlantic and southeastern US, genetic testing has indicated that as Coyotes moved eastward, a male Coyote hybridized with a female dog and their female hybrid offspring successfully bred with Coyotes (Adams et al. 2003b). Of 112 Coyotes tested from North Carolina, Virginia, and West Virginia, 12 had the same dog haplotype, indicating dog ancestry likely resulted from a single hybridization event (Adams et al. 2003b). Recently this haplotype has also been found in Tennessee, Kentucky, and Alabama (Dennis 2010).

Additionally, eastern Coyotes have hybridized with Canis lupus lycaon (Eastern Wolves) and Red Wolves. Studies have documented that Eastern Wolves have hybridized with Coyotes and that Eastern Wolf genetic material is present in the Coyote population in the northeast (Kays et al. 2010a, b; Way et al. 2010; Wheeldon et al. 2010; Wilson et al. 2009). Kays et al. (2010a) found Eastern Wolf genetic material in samples from central and western New York and Pennsylvania. However, because the locations at which specific samples were collected were not specified, it is unclear to what extent Eastern Wolf genetic material is present in the mid-Atlantic. Coyotes have also hybridized with Red Wolves in the Red Wolf 
recovery area in North Carolina to the extent that the US Fish and Wildlife Service recognizes hybridization as the primary threat to Red Wolf recovery (Adams 2003a, Roth et al. 2008). However, the extent to which Red Wolf DNA is present in the Coyote population outside of northeastern North Carolina is unknown.

\section{Morphology}

Coyotes are sexually dimorphic; males are larger and weigh more than females (Parker 1995). Adult Coyotes $(n=70)$ in Virginia averaged $16.2 \mathrm{~kg}$ and $13.4 \mathrm{~kg}$ for males and females, respectively (Houben and Mason 2004), whereas adult Coyotes $(n=39)$ in West Virginia averaged $14.4 \mathrm{~kg}$ and $11.9 \mathrm{~kg}$ for males and females, respectively (Wykle 1999). On average, male Coyotes in West Virginia were 122.6 $\mathrm{cm}$ long and females were $117.8 \mathrm{~cm}$ long (Wykle 1999). The largest published weight for a female eastern Coyote is $25.1 \mathrm{~kg}$ (Massachusetts) (Way and Poietto 2005). There are no published record weights of male eastern Coyotes, although 22.7-kg animals have been regularly recorded in Pennsylvania (Kyle Van Why, USDA Wildlife Services, Harrisburg, PA, pers. comm.). No other published information exists on the size and weights of Coyotes in the mid-Atlantic.

\section{Life history}

Pair bonding and mating. Pair bonding and mating occurs in January and February (Chambers 1992, Parker 1995). Coyotes are monogamous and maintain long-term pair bonds (Harrison 1992b). An instance of polygyny (1 male, 2 females) has been recorded in Coyotes in Ohio (Hennessy 2007). A survey in

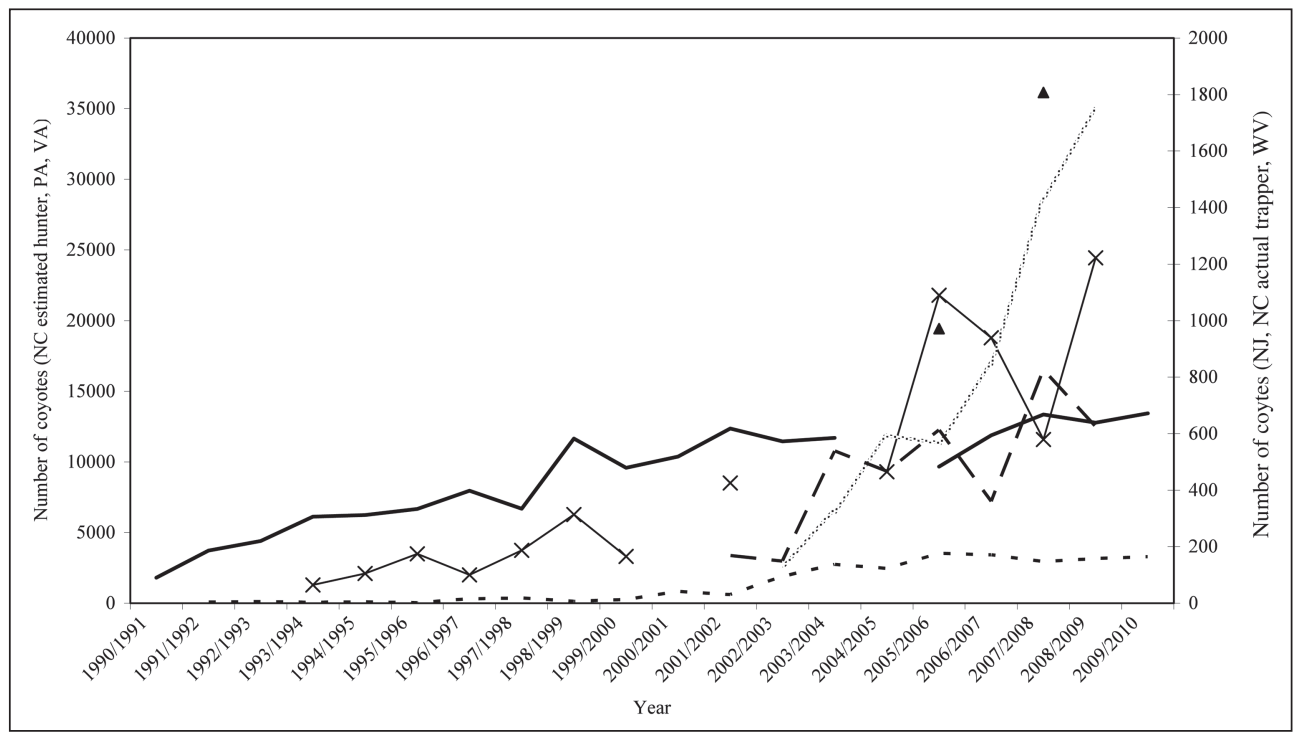

Figure 1. Coyote harvest in mid-Atlantic states as reported by state wildlife agencies 19902010. Estimated number of Coyotes harvested by hunters in North Carolina 2005/2006 and 2007/2008 ( $\boldsymbol{\Delta}$ ), Pennsylvania 1990-2004 and 2005-2010 (dark solid line), and Virginia 1993-2000, 2001/2002, and 2004-2009 (×'s). Actual number of Coyotes harvested by hunters and trappers in New Jersey 1991-2010 (short dashes). Actual number of Coyote pelts sold by trappers in West Virginia 2001-2009 (longer dashes). Actual number of Coyotes pelts sold by trappers and actual number of Coyotes harvested by trappers in North Carolina 2002-2009 (gray hashed line). 
western Tennessee found that $42 \%$ of females successfully mated and that older females were more likely to be pregnant than yearling females (Stephenson and Kennedy 1993). Overall, the number of breeding females is extremely variable and depends largely on local environmental conditions (Stephenson and Kennedy 1993). In Connecticut, only 6 of 27 (22\%) female reproductive tracts examined had placental scars (Parker 1995). In Massachusetts, females have been recorded whelping pups up to 6 years in a row (up to age 8-9) (Way and Proietto 2005).

Denning and birth. Gestation lasts about 60 days, and young are born in March and April (Parker 1995). Eastern Coyote den sites have been described as steep banks, rock ledges, brush-covered slopes, thickets, hollow logs, and above-ground depressions (Parker 1995, Way et al. 2001). In Massachusetts, 17 dens averaged $2.5 \mathrm{~m}$ deep, with an average minimum width of $28.9 \mathrm{~cm}$, and entrances faced no particular compass direction (Way et al. 2001). In Maine, 6 den entrances averaged a similar $37 \mathrm{~cm}$; however, these entrances were more likely to face south $\left(120-236^{\circ}\right)$ (Harrison and Gilbert 1985).

In western Tennessee, average litter size (based on placental scars) was 3.4 (Stephenson and Kennedy 1993). Litters in Massachusetts averaged 4.5 pups $(n=$ 16) (Way et al. 2001). The size of a litter is dependent on many factors including food availability and the ability of females to ovulate, conceive, and give birth (Parker 1995). Adults have been recorded moving their pups to other den sites up to 6 times (Harrison and Gilbert 1985, Way et al. 2001). New den sites were a mean distance of $1.6 \mathrm{~km}$ apart (Harrison and Gilbert 1985).

Pup development. Pups emerge from the den at 4-5 weeks of age (late May) (Harrison and Gilbert 1985, Harrison et al. 1991, Way et al. 2001). Dens are then abandoned at 8-10 weeks of age (June/July) for rendezvous or above-ground resting sites (Harrison and Gilbert 1985, Harrison et al. 1991, Way et al. 2001). Pups first begin to move short distances from den and rendezvous sites at 6-8 weeks of age, but still concentrate their activities at these sites (Harrison et al. 1991). Pups spend less time at the sites through the summer and eventually abandon them in mid-October (Harrison et al. 1991). Pups first move long distances accompanied by an adult at 13 weeks of age (late July; Harrison et. al 1991).

Pups are weaned by 6-8 weeks of age (Parks 1979, Silver and Silver 1969) and begin eating regurgitated food at 3 weeks (Parker 1995). Adults supply food (either regurgitated or whole) until July, and pups usually forage independently by August (Harrision et al. 1991). Pups may also receive food from adults that are not their parents (Way 2003, 2004; Way et al. 2001). A den of 4 pups in Massachusetts survived the death of their mother at 8 weeks of age because they were fed by at least 1 adult in addition to an animal presumed to be their surviving father (Way 2004). The genetic relationship between this adult and the pups was unknown (Way 2004).

Dispersal. Coyote pups in Maine dispersed 4-10 months after birth in two waves, October-November and January-February (Harrison et al. 1991). Males and females dispersed the same distance for an average of $102.5 \mathrm{~km}$ (Harrison 1992a). The distance and timing of dispersal is dependent upon food availability and population density (Bekoff 1978, Harrison et al. 1991).

Age structure and mortality. A sample of 70 adult Coyotes taken in western Virginia from 1993-1996 indicated that 71\% of Coyotes were greater than 1 year old (Houben and Mason 2004). The age structure of Coyotes in West Virginia 
is currently being examined (Albers 2010). The oldest documented wild eastern Coyote was a 10-12 year old female in Massachusetts that had produced a litter of pups in her last year of life (Way et al. 2004). The majority of mortalities among radio-collared adult Coyotes are human related, and include trapping, hunting, and road kills (Bogan 2004, Chamberlain and Leopold 2001, Hilton 1976, Schrecengost et al. 2009, and Van Deelen and Gosselink 2006).

\section{Social behavior}

Coyotes are a moderately social species, some are members of social groups which share the same territory, others are solitary and unassociated with other Coyotes. Eastern Coyotes typically live in groups of 2-4 (Caturano 1983, Way 2000). Observations of larger groups involve 3-4 adults and 5-7 pups (Patterson and Messier 2001, Way 2003). Groups of eastern Coyotes have been observed consisting of male/female, male/male, female/female pairs, as well as male/1-2 juveniles, 2 males/2 females, and male/female/1-3 juveniles (Brundige 1993, Caturano 1983, Major 1983, Patterson and Messier 2001, Way 2003).

A common misconception is that group members that are not the mated pair are always the offspring from the previous year. An Illinois study investigated the genetic relationship between eastern Coyote pack members (Hennessy 2007). Out of 116 relationships among 62 individual pack members: 49.1\% were fullsiblings or parent/offspring; 31\% were grandparent/grandchild, first cousins, aunt/nephew, etc.; $13.8 \%$ were unrelated; and $6.1 \%$ were mated pair relationships. Of the 7 mated pairs analyzed, 6 were unrelated and 1 was related on the level of grandparent/grandchild or first cousins. In most cases, pack members were related on some level; however, there were two individuals that were not related to any other member of their packs and a pack where none of the three members were related (Hennessy 2007).

\section{Home range}

Eastern Coyote home-range size varies and is influenced by habitat, geography, food availability, and season (Brundige 1993, Caturano 1983, Crête et al. 2001, Holzman et al. 1992, Person and Hirth 1991). Additionally, reproductive status, sex, and social status can also affect home-range size (Babb and Kennedy 1988, Harrison and Gilbert 1985, Parker and Maxwell 1989, Pearson and Hirth 1991, Way et al. 2002). Home ranges of Coyotes in the greater mid-Atlantic area vary greatly, and no geographic trends are evident (Table 1). Both the smallest $\left(5.7 \mathrm{~km}^{2}\right)$ and largest $\left(112.8 \mathrm{~km}^{2}\right)$ home ranges for eastern Coyotes have been observed in New York. There is currently no published data on home-range sizes in the mid-Atlantic region.

\section{Foraging ecology}

There is limited information on Coyote diet in the mid-Atlantic region. Two studies have been completed in northeastern Ohio, and one study each has been conducted in central Kentucky, Pennsylvania, and West Virginia (Table 2). Although these studies provide some baseline data, the availability of food due to season, prey population, or location limit the application of these data.

The first Ohio study, conducted during the winter, found that Microtus pennsylvanicus (Ord) (Meadow Vole) were in 14 of the 50 scats collected, but only 
accounted for $18 \%$ of diet by volume. Sylvilagus floridanus (J.A. Allen) (Eastern Cottontail) were in 10 of 50 scats and made up $13 \%$ of diet by volume. Whitetailed Deer were in 10 of 50 scats and comprised 13\% of diet by volume. Procyon lotor (L.) (Raccoon) were found in 9 of the 50 scats and comprised $12 \%$ of diet by volume (Cepek 2004). The second Ohio study, conducted during all seasons, also found that small mammals accounted for a large number of Coyote food items (490 of 944 scats contained small mammals). Small mammals were followed by White-tailed Deer (415 of 944 scats), vegetation (305 of 944 scats), and Eastern Cottontail (142 of 944 scats). This latter study did not examine food items by volume (Bollin-Booth 2007).

The Pennsylvania study, conducted year round, found that vegetation occurred in 177 of 310 scats and White-tailed Deer were observed in 171 of 310 scats. Other

Table 1: Mean annual home ranges $\left(\mathrm{km}^{2}\right)$ of adult Coyotes in the eastern United States. $n=$ the number of Coyotes a given mean home range is for, $\mathrm{MCP}=$ minimum convex polygon

\begin{tabular}{|c|c|c|c|c|}
\hline State(s) & $\begin{array}{l}\text { Home range } \\
\text { size }\left(\mathrm{km}^{2}\right)\end{array}$ & $n$ & Method & Source \\
\hline Massachusetts & 50.7 & 7 & $95 \% \mathrm{MCP}$ & (Way et al. 2002) \\
\hline New York & 5.7 & 17 & $95 \% \mathrm{MCP}$ & (Bogan 2004) \\
\hline New York & 112.8 & 10 & $95 \% \mathrm{MCP}$ & (Brundige 1993) \\
\hline New York & 17.4 & 9 & $95 \% \mathrm{MCP}$ & (Kendrot 1998) \\
\hline New Jersey & 10.4 & 4 & $95 \% \mathrm{MCP}$ & (Eastman 2000) \\
\hline Indiana & 9.9 & 2 & $95 \%$ adaptive kernel & (Atwood and Weeks 2002) \\
\hline Kentucky & 18.4 & 6 & $95 \%$ adaptive kernel & $(\operatorname{Cox} 2003)$ \\
\hline Tennessee & 42.6 & 5 & Minimum area & (Babb and Kennedy 1988) \\
\hline South Carolina & 30.5 & 18 & $95 \% \mathrm{MCP}^{\mathrm{a}}$ & (Schrecengost 2007) \\
\hline
\end{tabular}

Table 2. Prey items found in $>15 \%$ of samples (scat or stomach) in Coyote diet studies conducted in mid-Atlantic and adjacent states. $n=$ total number of samples.

\begin{tabular}{|c|c|c|c|}
\hline $\begin{array}{l}\text { Location } \\
\text { (author) }\end{array}$ & Season & Sample type $(n)$ & $\begin{array}{l}\% \text { of samples } \\
\text { containing a food item }\end{array}$ \\
\hline $\begin{array}{l}\text { Kentucky } \\
\text { (Crosset and Elliott 1991) }\end{array}$ & Winter & Stomach (66) & $\begin{array}{l}52 \% \text { small mammals } \\
26 \% \text { cattle } \\
20 \% \text { Eastern Cottontail }\end{array}$ \\
\hline $\begin{array}{l}\text { Ohio } \\
\text { (Bollin-Booth 2007) }\end{array}$ & Year-round & Scat (944) & $\begin{array}{l}52 \% \text { small mammal } \\
44 \% \text { White-tailed Deer } \\
32 \% \text { vegetation } \\
15 \% \text { Eastern Cottontail }\end{array}$ \\
\hline $\begin{array}{l}\text { Ohio } \\
\text { (Cepek 2004) }\end{array}$ & Winter & Scat (50) & $\begin{array}{l}28 \% \text { Meadow Vole } \\
20 \% \text { Eastern Cottontail } \\
20 \% \text { White-tailed Deer } \\
18 \% \text { Raccoon }\end{array}$ \\
\hline $\begin{array}{l}\text { Pennsylvania } \\
\text { (Witmer et al. 1995) }\end{array}$ & Year-round & Scat (310) & $\begin{array}{l}55 \% \text { vegetation } \\
55 \% \text { White-tailed Deer } \\
18 \% \text { insects } \\
16 \% \text { fruit } \\
15 \% \text { small mammals }\end{array}$ \\
\hline $\begin{array}{l}\text { West Virginia } \\
\text { (Wykle 1999) }\end{array}$ & Winter & Stomach (24) & $\begin{array}{l}83 \% \text { White-tailed Deer } \\
17 \% \text { fruit }\end{array}$ \\
\hline
\end{tabular}


food items of importance were insects (56 of 310 scats), fruit (49 of 310 scats), and small mammals (46 of 310 scats). Again, this study did not examine food items by volume (Witmer et al. 1995). The central Kentucky study, conducted only in winter, found that small mammals occurred in more stomachs than any other food item (34 of 66 stomachs), followed by Bos Taurus L. (Cattle) (17 of 66 stomachs) and Eastern Cottontail (13 of 66 stomachs). Samples were collected by private fur trappers, fur dealers, farm bureau personnel, and Kentucky Department of Fish and Wildlife Resources personnel. Again, this study did not examine food items by volume (Crossett and Elliott 1991). The West Virginia study, conducted primarily in winter, collected 24 Coyote stomachs from private fur trappers and USDA APHIS Wildlife Services specialists. The most frequently occurring food item was White-tailed Deer (20 of 24 stomachs), followed by fruit (4 of 24 stomachs), small mammals ( 2 of 24 stomachs), and Ovis ovies (Sheep) (2 of 24 stomachs). This study also did not examine food items by volume (Wykle 1999). The year-round diet of Coyotes in West Virginia is currently being examined (Albers 2010).

\section{Conclusion}

Coyotes have recently expanded their range into the mid-Atlantic region raising concerns about their impacts to both wildlife and domestic livestock. A review of the literature found that gaps in our knowledge were apparent in all areas of the ecology of eastern Coyotes. Deficiencies in the quality and quantity of information about the mid-Atlantic Coyotes' population, social behavior, home range, and foraging ecology are of particular concern, as this information is necessary for wildlife managers to assess and address their impacts and changing role in local ecosystems. Information on Coyote foraging ecology, population density, home range, ecological impacts, and genetics from areas outside the mid-Atlantic states may not be applicable due to ecological and environmental differences. Thus, these areas should be priorities of future research.

\section{Acknowledgments}

I am grateful to Marilyn Howell and the NWRC library for their assistance obtaining documents. Andrew Burnett (New Jersey Division of Fish and Wildlife), Mike Fies (Virginia Department of Game and Inland Fisheries), Thomas Hardisky (Pennsylvania Game Commission), Colleen Olfenbuttel (North Carolina Wildlife Resources Commission), and Rich Rogers (West Virginia Division of Natural Resources), generously provided Coyote harvest statistics. Scott C. Barras and Julie K. Young reviewed the manuscript. Christopher K. Croson and Scott C. Barras provided logistical support.

\section{Literature Cited}

Adams, J.R., B.T. Kelly, and L.P. Waits. 2003a. Using faecal DNA sampling and GIS to monitor hybridization between Red Wolves (Canis rufus) and Coyotes (Canis latrans). Molecular Ecology 12:2175-2186.

Adams, J.R., J.A. Leonard, and L.P. Waits. 2003b. Widespread occurrence of a domestic dog mitochondrial DNA haplotype in southeastern US Coyotes. Molecular Ecology 12:541-546.

Albers, G. 2010. Seasonal diets of Coyotes in West Virginia. M.Sc. Thesis proposal. West Virginia University, Morgantown, WV. 
Anderson, T.M., B.M. vonHoldt, S.I. Candille, M. Musiani, C. Greco, D.R. Stahler, D.W. Smith, B. Padhukasahasram, E. Randi, J.A. Leonard, C.D. Bustamante, E.A. Ostrander, H. Tang, R.K. Wayne, and G.S. Barsh. 2009. Molecular and evolutionary history of melanism in North American Gray Wolves. Science 323:1339-1343.

Atwood, T.C., and H.P. Weeks, Jr.. 2002. Spatial home-range overlap and temporal interaction in eastern Coyotes: The influence of pair types and fragmentation. Canadian Journal of Zoology 81:1589-1597.

Babb, J.G., and M.L. Kennedy. 1988. Home range of the Coyote in western Tennessee. Proceedings of the Annual Conference of Southeastern Fish and Wildlife Agencies 42:443-447.

Bekoff, M. 1978. Behavioral development in Coyotes and eastern Coyotes. Pp. 97-127, In M. Bekoff (Ed.). Coyotes: Biology, Behavior, and Management. 2001 reprint. Blackburn Press, Caldwell, NJ. 384 pp.

Bogan, D.A. 2004. Eastern Coyote (Canis latrans) home range, habitat selection, and survival rates in the suburban Albany pine bush landscape of New York. M.Sc. Thesis. State University of New York at Albany, Albany, NY. 83 pp.

Bollin-Booth, H.A. 2007. Diet analysis of the Coyote (Canis latrans) in metropolitan park systems of northeast Ohio. M.Sc. Thesis. Cleveland State University, Cleveland, OH. 38 pp.

Brundige, G.C. 1993. Predation ecology of the eastern Coyote, Canis latrans var., in the Adirondacks, New York. Ph.D. Dissertation. State University of New York, Syracuse, NY. 196 pp.

Caturano, S.L. 1983. Habitat and home-range use by Coyotes in eastern Maine. M.Sc. Thesis. University of Maine, Orono, ME. 28 pp.

Cepek, J.D. 2004. Diet composition of Coyotes in the Cuyahoga Valley National Park, Ohio. Ohio Journal of Science. 104:60-64.

Chamberlain, M.J., and B.D. Leopold. 2001. Survival and cause-specific mortality of adult Coyotes (Canis latrans) in central Mississippi. American Midland Naturalist 145:414-418.

Chambers, R.E. 1992. Reproduction of Coyotes in their northeastern range. Pp. 39-52, In A.H. Boer (Ed.). Ecology and management of the eastern Coyote. Wildlife Research Unit, University of New Brunswick, Fredericton, NB, Canada. 194 pp.

Cox, J.J. 2003. Community dynamics among reintroduced Elk, White-tailed Deer, and Coyote in southeastern Kentucky. Ph.D. Dissertation. University of Kentucky, Lexington, KY. 288 pp.

Crête, M., J.-P. Ouellet, J.-P. Tremblay, and R. Arsenault. 2001. Suitability of the forest landscape for Coyotes in northeastern North America and its implications for coexistence with other carnivores. Ecoscience 8:311-319.

Crossett III, R.L., and C.L. Elliott. 1991. Winter food habits of Red Foxes and Coyotes in central Kentucky. Proceedings of Annual Conference of Southeastern Fish and Wildlife Agencies 45:97-103.

DeBow, T.M., W.D. Webster, and P.W. Sumner. 1998. Range expansion of the Coyote, Canis latrans (Carnivora: Canidae), into North Carolina, with comments on some management implications. Journal of the Elisha Mitchell Scientific Society 114:113-118.

Dennis, D.L. 2010. Genetic analysis of dispersal and population dynamics of the southeastern Coyote (Canis latrans). Ph.D. Dissertation. Auburn University, Auburn, AL. 79 pp.

Fener, H.M., J.R. Ginsberg, E.W. Sanderson, and M.E. Gompper. 2005. Chronology of range expansion of the Coyote, Canis latrans, in New York. Canadian Field Naturalist 119:1-5.

Eastman, S.A. 2000. Home ranges and diseases of Coyotes (Canis latrans) in northwestern New Jersey and northeastern Pennsylvania. M.Sc. Thesis. East Stroudsburg University, East Stroudsburg, PA. 71 pp. 
Harrison, D.J. 1992a. Dispersal characteristics of juvenile Coyotes in Maine. Journal of Wildlife Management 56:128-138.

Harrison, D.J. 1992b. Social ecology of Coyotes in northeastern North America: Relationships to dispersal, food resources, and human exploitation. Pp. 53-72, In A.H. Boer (Ed.). Ecology and Management of the Eastern Coyote. Wildlife Research Unit, University of New Brunswick, Fredericton, NB, Canada. 194 pp.

Harrison, D.J., and J.R. Gilbert. 1985. Denning ecology and movements of Coyotes in Maine during pup rearing. Journal of Mammalogy 66:712-719.

Harrison, D.J., J.A. Harrison, and M. O’Donoghue. 1991. Predispersal movements of Coyote in eastern Maine. Journal of Mammalogy 72:756-763.

Hayden, A. 2003. Coyote: Wildlife note 39. Pennsylvania Game Commission, Harrisburg, PA. 2 pp.

Hennessy, C.A. 2007. Mating strategies and pack structure of Coyotes in an urban landscape: A genetic investigation. M.Sc. Thesis. Ohio State University, Columbus, OH. 120 pp.

Hilton, H. 1976. The physical characteristics, taxonomic status, and food habits of the eastern Coyote in Maine. M.Sc. Thesis. University of Maine, Orono, ME. 66 pp.

Holzman, S, M.J. Conroy, and J. Pickering. 1992. Home range, movements, and habitat use of Coyotes in south-central Georgia. Journal of Wildlife Management 56:139-146.

Houben, J.M., and J.R. Mason. 2004. Weight and age of Coyotes captured in Virginia, USA. Proceedings of Vertebrate Pest Conference 21:75-76.

Kays, R.W., A. Curtis, and J. Kirchman. 2010a. Rapid adaptive evolution of northeastern Coyotes via hybridization with Wolves. Biology Letters 6:89-93.

Kays, R.W., A. Curtis, and J. Kirchman. 2010b. Reply to Wheeldon et al. "Colonization history and ancestry of northeastern Coyotes". Biology Letters 6:248-249.

Kendrot, S.R. 1998. The effects of roads and land use on home-range use, behavior, and mortality of eastern Coyotes (Canis latrans var.) in northern New York. M.Sc. Thesis. State University of New York, Syracuse, NY. 83 pp.

Lee, D.S., J.B. Funderburg, Jr., and M.K. Clark. 1982. A distributional survey of North Carolina Mammals. Occasional Papers of the North Carolina Biological Survey 10:1-70.

Linzey, D.W. 1998. Mammals of Virginia. McDonald and Woodard, Blacksburg, VA. $480 \mathrm{pp}$.

Lund, R.C. 1975. Status of the eastern Coyote in New Jersey. Pp. 41-47, In R.E. Chambers (Ed.). Transactions of the Eastern Coyote Workshop. Northeast Fish and Wildlife Conference, 23-26 February 1975, New Haven, CT. 98 pp.

Major, J.T. 1983. Ecology and interspecific relationships of Coyotes, Bobcats, and Red Foxes in western Maine. M.Sc. Thesis. University of Maine, Orono, ME. 63 pp.

McGinnis, H.J. 1979. Pennsylvania Coyotes and their relationship to other wild Canis populations in the Great Lakes region and the northeastern United States. M.Sc. Thesis. Pennsylvania State University, State College, PA. 227 pp.

Moore, G.C., and G.R. Parker. 1992. Colonization by the eastern Coyote (Canis latrans). Pp. 23-37, In A.H. Boer (Ed.). Ecology and Management of the Eastern Coyote. Wildlife Research Unit, University of New Brunswick, Fredericton, NB, Canada. 194 pp.

National Agricultural Statistics Service (NASS). 1992. Cattle and calves death loss. United States Department of Agriculture, Washington, DC. 23 pp.

NASS. 2006. Cattle death loss. United States Department of Agriculture, Washington, DC. 15 pp.

Parker, G.E. 1995. Eastern Coyote: The story of its success. Nimbus, Halifax, NS, Canada. 254 pp.

Parker, G.R., and J.W. Maxwell. 1989. Seasonal movements and winter ecology of the Coyote, Canis latrans, in northern New Brunswick. Canadian Field Naturalist 103:1-11. 
Parks, M.B. 1979. Physical and behavioral development of captive eastern Coyote pups. M.Sc. Thesis. University of Maine, Orono, ME. 60 pp.

Patterson, B.R., and F. Messier. 2001. Social organization and space use of Coyotes in eastern Canada relative to prey distribution and abundance. Journal of Mammalogy 82:463-477.

Person, D.A., and D.H. Hirth. 1991. Home range and habitat use of Coyotes in a farm region in Vermont. Journal of Wildlife Management 55:433-441.

Roth, J.D., D.L. Murray, and T.D. Steury. 2008. Spatial dynamics of sympatric canids: Modeling the impact of Coyotes on Red Wolf recovery. Ecological Modeling 214:391-403.

Schrecengost, J.D., J.C. Kilgo, H.S. Ray, and K.V. Miller. 2009. Home range, habitat use, and survival of Coyotes in western South Carolina. American Midland Naturalist 162:346-355.

Silver, H., and W.T. Silver. 1969. Growth and behavior of the Coyote-like canid of northern New England with observations on canid hybrids. Wildlife Monographs $17: 1-41$.

Stephenson, S.W., and M.L. Kennedy. 1993. Demography of a Coyote population in western Tennessee. Journal of the Tennessee Academy of Science 68:122-124.

Van Deelen, T.R., and T.E. Gosselink. 2006. Coyote survival in a row-crop agricultural landscape. Canadian Journal of Zoology 84:1630-1636.

Way, J.G. 2000. Ecology of Cape Cod Coyotes (Canis latrans var.). M.Sc. Thesis. University of Connecticut, Storrs, CT. 107 pp.

Way, J.G. 2003. Description and possible reasons for an abnormally large group size of adult eastern Coyotes observed during summer. Northeastern Naturalist 10:335-342.

Way, J.G. 2004. Survival of 8-week-old eastern Coyote pups following the death of their mother. Northeastern Naturalist 11:66-71.

Way, J.G. 2007. Social and play behavior in a wild eastern Coyote, Canis latrans, pack. Canadian Field Naturalist 121:397-401.

Way, J.G., and R.L. Proietto. 2005. Record size female Coyote, Canis latrans. Canadian Field Naturalist 119:139-140.

Way, J.G., P.J. Auger, I.M. Ortega, and E.S. Strauss. 2001. Eastern Coyote denning behavior in an anthropogenic environment. Northeast Wildlife 56:18-30.

Way, J.G., I.M. Ortega, P.J. Auger. 2002. Eastern Coyote home range, territoriality, and sociality on urbanized Cape Cod. Northeast Wildlife 57:1-18.

Way, J.G., I.M. Ortega, and E.G. Strauss. 2004. Movement and activity patterns of eastern Coyotes in a coastal, suburban environment. Northeastern Naturalist 11:237-254.

Way, J.G., L. Rutledge, T. Wheeldon, B.N. White. 2010. Genetic characterization of eastern "Coyotes" in eastern Massachusetts. Northeastern Naturalist. 17:189-204.

Wheeldon, T., B. Patterson, and B. White. 2010. Comment: Colonization history and ancestry of northeastern Coyotes. Biology Letters 6:246-247.

Williams, S.L., S.B. McLaren, and M.A. Burgwin. 1985. Paleo-archaeological and historical records of selected Pennsylvania mammals. Annals of Carnegie Museum 54:77-188.

Wilson, P., S. Grewal, F.F. Mallory, and B.N. White. 2009. Genetic characterization of hybrid wolves across Ontario. Journal of Heredity 100:S80-S89.

Witmer, G.W., M.J. Pipas, and A. Hayden. 1995. Some observations on Coyote food habits in Pennsylvania. Journal of the Pennsylvania Academy of Science 69:77-80.

Wykle, J. 1999.The status of the Coyote, Canis latrans, in West Virginia. M.Sc. Thesis. Marshall University, Huntington, WV. 131 pp. 